\title{
EFEKTIVITAS PENINGKATAN PENGETAHUAN KESEHATAN GIGI DAN MULUT MENGGUNAKAN MEDIA VIDEO DAN PERMAINAN ULAR TANGGA PADA SISWA SEKOLAH DASAR
}

\author{
Obed Kris Setiadi ${ }^{1}$, Natalia Ratna Yulianti ${ }^{2}$, Eka Wahyuningrum ${ }^{3}$, Caecilia Nancy ${ }^{4}$ \\ 1,3 Program Studi S1 Ilmu Keperawatan, STIKes St. Elisabeth Semarang \\ 2 Program Profesi Ners, STIKes St. Elisabeth Semarang \\ ${ }^{4}$ RS St. Elisabeth Semarang \\ Corresponding Email: \\ Corresponding author: natalia.r.yulianti@gmail.com
}

\begin{abstract}
Abstrak
Pendahuluan: Karies gigi dapat menyebabkan masalah kesehatan serius pada anak sekolah. Anak akan memiliki risiko tinggi mengalami penurunan prestasi belajar dan kekurangan nutrisi. Pendidikan kesehatan dengan cara bermain dapat dilakukan untuk mencegah kejadian tersebut. Terdapat dua permainan yang terbukti efektif sebagai pendukung pendidikan kesehatan yaitu permainan ular tanga dan menonton video. Namun belum ada penelitian yang menunjukkan permainan yang paling efektif untuk pendidikan kesehatan. Penelitian ini bertujuan untuk menginvestiasi perbedaan peningkatan pengetahuan menggunakan permainan ular tangga dan video. Metode: Penelitian ini menggunakan desain pretest-posttest nonequivalent control group. Sampel sebanyak 74 responden dibagi menjadi 2 kelompok, kelompok yang melakukan permainan ular tangga dan kelompok yang menonton video. Masing-masing kelompok terdiri dari 37 responden. Sampel didapatkan dengan menggunakan consecutive sampling. Hasil: Penelitian ini menunjukkan bahwa pendidikan kesehatan dengan permainan ular tangga lebih efektif dalam meningkatkan pengetahuan dibandingkan dengan cara menonton video. Rerata peningkatan pada kelompok ular tangga adalah 6,35 dan video adalah 2,14. Uji alternative Mann-Whitney menghasilkan $\mathrm{p}$ value $<0,001(\mathrm{p}<0.05)$. Simpulan: Terdapat perbedaan peningkatan pengetahuan pada kelompok pendidikan kesehatan dengan permainan ular tangga dan menonton video.
\end{abstract}

Kata kunci: anak usia sekolah, kesehatan gigi, pendidikan kesehatan, ular tangga, video

\section{Abstract}

Background: Dental caries may cause serious health problems in school children. This put children on high risk of school achievement decreasing and lack of nutrition. It is important to provide them a health education which could be done by play program. There were two play programs proven as effective for health education namely snake ladder and watching video. However, little is known which program is more effective. This study aimed to investigate differences of increasing dental and mouth health knowledge using snake lader media and video. 
Methods: This study employed Pretest-Posttest nonequivalent control group design and conducted in Candi 01 Elementary School, Semarang City. The sample of 74 people divided into 2 groups, snake ladder group and video. Each group consisted of 37 people. Technique sampling adopted in this study was consecutive sampling. Result: It was found that the snake ladder game was more effective in increasing health knowledge. The average increasing point in snake ladder group was 6.35 and in video group was 2.14. Mann-Whitney alternative test resulted the $p$ value $<0.01$ ( $p<0.05$ ). Conclusion: There were differences in the benefits of health and oral knowledge using media videos and snake games on Candi 01 elementary school students in Semarang City.

Keywords: dental health, health education, school-aged children, snake lather, video.

\section{Pendahuluan}

Anak usia sekolah merupakan masa rentan terhadap masalah kesehatan gigi dan mulut. Pada usia tersebut merupakan usia awal di mana gigi susu mulai berganti menjadi gigi permanen.Adanya perubahan tersebut membuat gigi lebih rentan mengalami kerusakan. Pada umumnya kebersihan mulut anak lebih burukdikarenakan anak lebih banyak mengonsumsi makanan dan minuman yang menyebabkan karies gigi dibanding dengan orang dewasa. Karies gigi menjadi salah satu masalah kesehatan serius pada anak usia sekolah. Karies gigi dapat merusak struktur gigi dan menyebabkan gigi berlubang.(Harlina, 2011; Potter \&Perry, 2012)

Gigi berlubang dapat menyebabkan infeksi yang akan menimbulkan rasa sakit pada anak. Anak menjadi tidak dapat melakukan kegiatan sehari-hari termasuk belajar sehingga anak harus tinggal di rumah. Selain itu, napsu makan anak juga akan berkurang dan anak berisiko mengalami gangguan nutrisi.(Potter \&Perry, 2012) Hal ini dapat dicegah dengan pemeliharaan kesehatan gigi sejak dini.

Kesadaran anak untuk melakukan pemeliharaan kesehatan gigi dapat ditumbuhkan dengan pendidikan kesehatan. Pembelajaran pada anak dapat dilakukan dengan cara bermain. Pendidkan pemograman di Sweden dilakukan dengan metode play-based learning atau pembelajaran berdasarkan kegiatan bermain. Hasil penelitian tersebut menunjukkan bahwa metode tersebut mendukung pembelajaran pemograman karena anak menikmati seluruh sesi pembelajaran (Mozelius \& Öberg, 2017). Sementara di Skotlandia, kegiatan bermain memiliki nilai positif dalam pendidikan dan cenderung diterapkan oleh para praktisi pendidikan di sana (Mckendrick, 2019) .

Kegiatan bermain juga dapat diterapkan sebagai media pendidikan non formal, seperti pendidikan kesehatan. Beberapa penelitian telah menguji keefektifan permainan tertentu sebagai media pembelajaran pendidikan kesehatan pada anak, seperti penelitian (Hamdalah, 2013) yang membuktikan bahwa permainan ular tangga terbukti lebih efektif sebagai media pembelajaran dibandingkan dengan kegiatan mewarnai dan penelitian (Kantohe, Wowor, \& Gunawan, 2016)yang menemukan bahwa media video lebih efektif dibandingkan dengan media flip chart. 
Kedua penelitian tersebut merekomendasikan dua kegiatan bermain yang terbukti efektif sebagai media pendidikan kesehatan yaitu permainan ular tangga dan video. Pemberi pendidikan kesehatan perlu mendapatkan rekomendasi terbaik diantara kedua permainan tersebut. Sayangnya belum ada penelitian yang menguji diantara kedua kegiatan tersebut mana yang lebih efektif. Oleh karena itu, penelitian ini bertujuan untuk mengidentifikasi perbedaan keefektifan antara permainan ular tangga dan video sebagai media pendidikan kesehatan gigi bagi anak usia sekolah.

\section{Metode}

Penelitian ini merupakan penelitian kuantitatif dengan pendekatan PretestPosttest nonequivalent control group design (Wahyuningrum, Rahmat, \& Hartini, 2018). Dalam penelitian ini peneliti memberikan pretestdan posttest pada masing - masing kelompok intervensi kemudian mengamati perbedaan selisih yang terjadi pada dua metode yang dibandingkan (video dan ular tangga) dengan hipotesis H0: tidak ada perbedaaan rerata selisih pengetahuan tentang kesehatan gigi dan mulut antara pendidikan kesehatan bermedia permainan ular tangga dan pendidikan kesehatan bermedia video pada siswa SDN Candi 01 Semarang dan H1: Ada perbedaaan rerata selisih pengetahuan tentang kesehatan gigi dan mulut antara pendidikan kesehatan bermedia permainan ular tangga dan pendidikan kesehatan bermedia video pada siswa SDN Candi 01 Semarang.

Populasi dalam penelitian ini adalah siswa SDN Candi 01 Semarang yang berusia 8 tahun. Sampel adalah sebagian dari jumlah dan karakteristik yang dimiliki oleh populasi. Sampel dalam penelitian ini adalah siswa SDN 01 Semarang yang berusia 8 tahun pada saat penelitian. Sampel yang digunakan memenuhi kriteria inklusi: responden berusia 8 tahun, responden yang belum mendapatkan pendidikan kesehatan tentang kesehatan gigi dan mulut sebelumnya, setuju untuk menjadi respon, dan anak yang bisa membaca dan menulis, dan kriteria ekslusi responden yang sedang sakit. Penentuan jumlah sampel dilakukan dengan perhitungan rumus slovin:

$$
\begin{aligned}
& n=\frac{N}{1+N(d)^{2}} \\
& n=\frac{90}{1+90(0,05)^{2}} \\
& n=73,469=74
\end{aligned}
$$

Tehnik pemilihan sampel pada penelitian ini adalah consecutive sampling.

Data dikumpulkan dengan prosedur: melakukan pretest yaitu dengan mengukur pengetahuan kesehatan gigi dan mulut dengan kuesioner selama 50 menit, segera setelah pretest, responden langsung dibagi menjadi dua kelompok sesuai dengan nomer urut. Kelompok 1 mendapatkan pendidikan kesehatan dengan media video dan Kelompok 2mendapatkan pendidikan kesehatan dengan media permainan ular tangga, memberikan pendidikankesehatan kepada kedua kelompok. Kelompok 1 didampingi oleh asisten peneliti. Kelompok 2didampingi oleh peneliti; Melakukan post test yaitu dengan mengukur pengetahuan kesehatan gigi dan mulut dengan kuesioner selama 50 menit;:Mencatat hasilnya dilembar observasi

Perbedaan selisih rerata pengetahuan antara kelompok yang mendapatkan pendidikan kesehatan media video dan media ulartangga diuji dengan menggunakan uji mann whitney, karena distribusi data tidak normal. Uji Shapiro Wilk dilakukan untuk mengetahui sebaran data pada data sebelum dan sesudah 
intervensi pada setiap kelompok. Hasil menunjukkan $\mathrm{p}$ value $<0,05$ yang berarti distribusi data tidak normal.

\section{a. Karakteristik Responden Berdasarkan Jenis Kelamin}

\section{Hasil}

\section{Karakteristik responden}

Karakteristik Responden Berdasarkan Jenis Kelamin

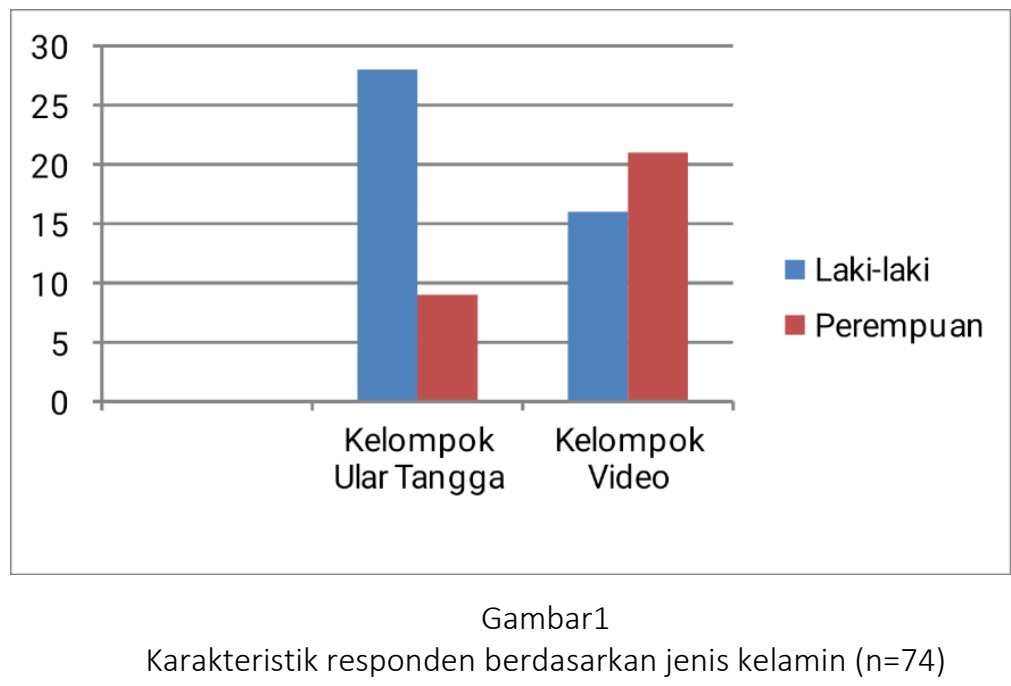

Gambar 1 menunjukan responden yang mendapat pendidikan kesehatan bermedia ular tangga sebagian besar berjenis kelamin laki-laki $(75,7 \%)$. Berbeda dengan respondenyang mendapat pendidikan kesehatan bermedia video, jumlah responden paling banyak adalah perempuan $(56,8 \%)$. b. Karakteristik Responden Berdasarkan Kelas

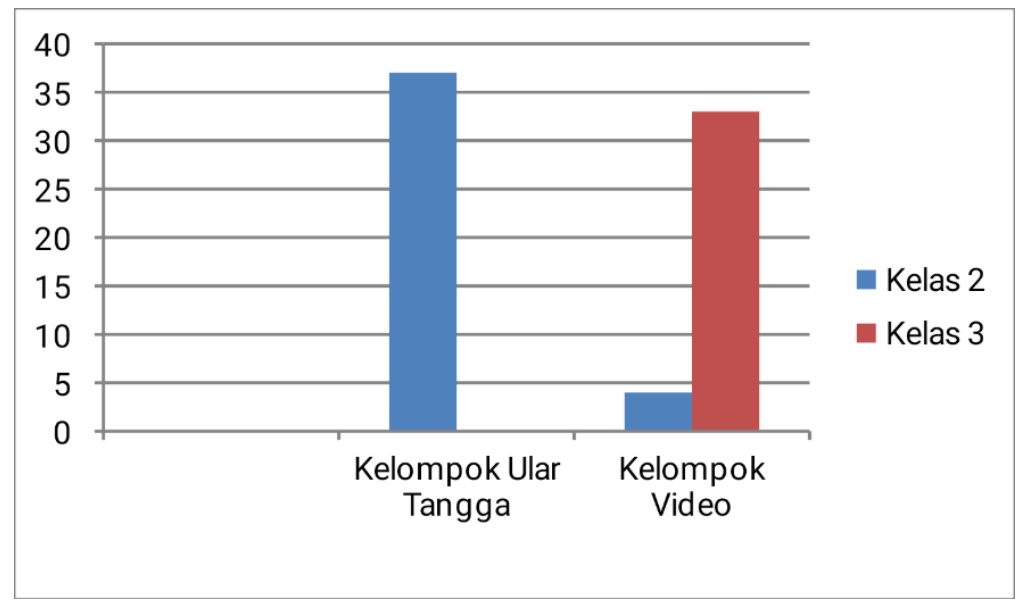


Gambar 2 menunjukan semua responden pada pendidikan kesehatan bermedia ular tangga adalah kelas 2 (100\%). Sedangkan responden pada pendidikan kesehatan bermediavideo sebagian besar adalah kelas $3(89,2 \%)$.

\section{c. Pengaruh pendidikan kesehatan tentang kesehatan gigi dan mulut dengan media permainan ular tangga terhadap pengetahuan tentang kesehatan gigidan mulut}

Tabel 1

Pengaruh pendidikan kesehatan tentang kesehatan gigi dan mulut dengan media permainan ular tangga terhadap pengetahuan tentang kesehatan gigi dan mulut

\begin{tabular}{cccc}
\hline $\begin{array}{c}\text { Jumlah } \\
\text { Jawaban } \\
\text { Benar }\end{array}$ & $\mathrm{n}$ & $\begin{array}{c}\text { Nilai rata-rata } \\
\pm \text { s.d }\end{array}$ & Selisih \\
\hline Sebelum & 37 & $8,68 \pm 1,88$ & 6,35 \\
Sesudah & 37 & $15,03 \pm 2,42$ & \\
\hline
\end{tabular}

Tabel 1 menunjukan selisih jumlah jawaban benar kuesioner sebelum dan sesudah bermain ular tangga pada kelompok ular tangga sebesar 6,35. Jumlah jawaban benar lebih banyak pada responden yang sudah mendapatkan pendidikan kesehatan tentang kesehatan gigi dan mulut dengan permainan ular tangga.

d. Jumlah jawaban benar sebelum dan sesudah pada pendidikan kesehatan bermedia ular tangga

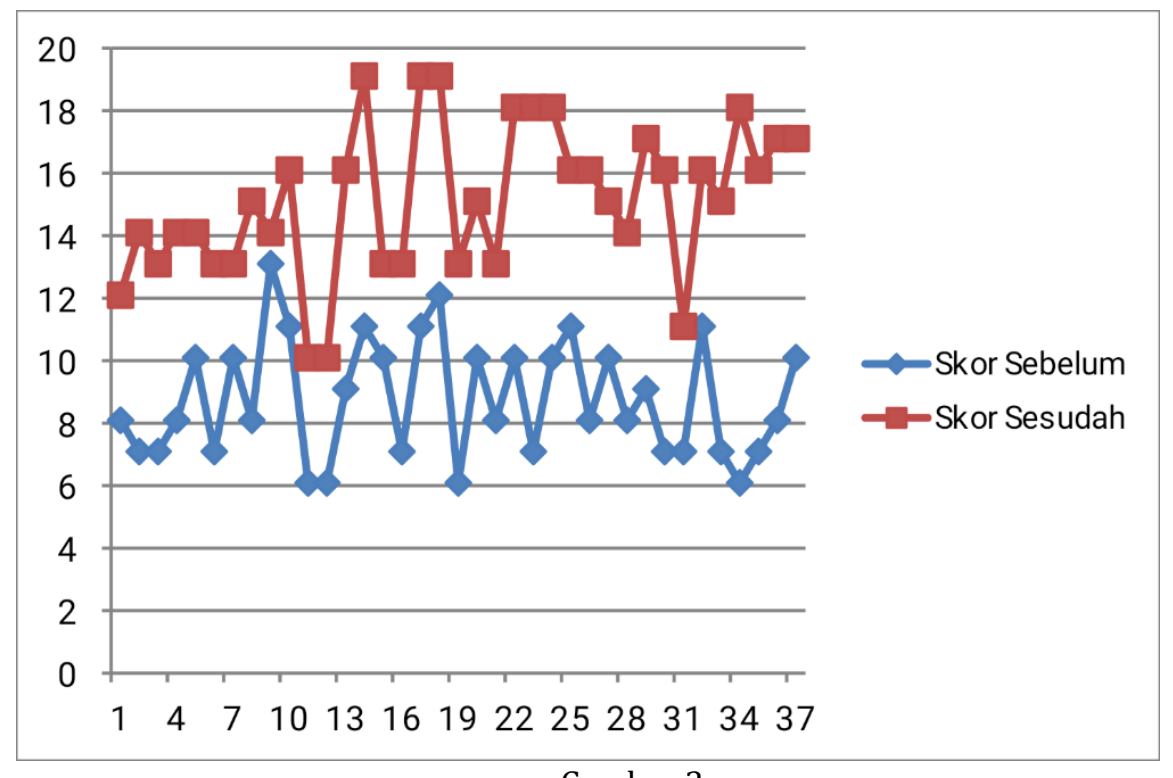

Gambar 3

Jumlah jawaban benar sebelum dan sesudah pada pendidikan kesehatan bermedia ular tangga $(n=37)$ 
Gambar 4.3 menunjukan semua responden mengalami peningkatan pengetahuan. Jumlah jawaban benar sebelum bermain ular tangga paling rendah 6 dan paling tinggi 13. Sedangkan jumlah jawaban benar sesudah pendidikan kesehatan dengan bermain ular tangga paling rendah 10 dan paling tinggi 19. e. Pengaruh pendidikan kesehatan tentang kesehatan gigi dan mulut dengan media video terhadap pengetahuan tentang kesehatan gigi dan mulut

Tabel 2

Pengaruh pendidikan kesehatan tentang kesehatan gigi dan mulut dengan media video terhadap pengetahuan tentang kesehatan gigi dan mulut

\begin{tabular}{cccc}
\hline $\begin{array}{c}\text { Jumlah } \\
\text { Jawaban } \\
\text { Benar }\end{array}$ & N & $\begin{array}{c}\text { Nilai rata-rata } \\
\pm \text { s.d }\end{array}$ & Selisih \\
\hline Sebelum & 37 & $8,89 \pm 1,82$ & 2,14 \\
Sesudah & 37 & $11,03 \pm 2,21$ & \\
\hline
\end{tabular}

Tabel2menunjukkan selisih jumlah jawaban benar kuesioner sebelum dan sesudah menonton video pada kelompok video sebesar 2,14. Jumlah jawaban benar lebih banyak pada responden yang sudah mendapatkan pendidikan kesehatan tentang kesehatan gigi dan mulut dengan media video.

\section{f. Jumlah Jawaban Benar Sebelum dan Sesudah pada Kelompok Video}

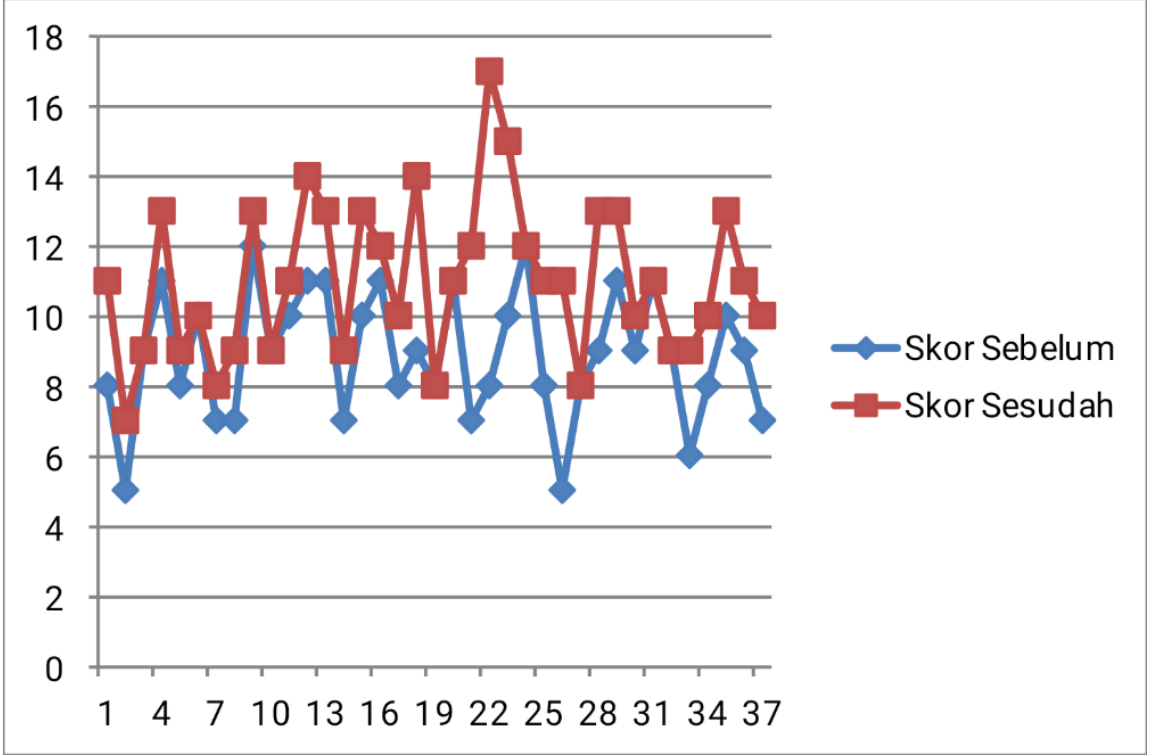

Gambar 4.4

Jumlah jawaban benar sebelum dan sesudah pada pedidikan kesehatan bermedia video 
Gambar 4menunjukan semua responden mengalami peningkatan pengetahuan. Jumlah jawaban benar sebelum mendapatkan pendidikan kesehatan bermedia videopaling rendah 5 dan paling tinggi 12 . Sedangkan jumlah jawaban benar sesudah pendidikan kesehatan dengan media videopaling rendah 7 dan paling tinggi 17.

\section{g. Hasil Analisis Uji Perbedaan pada Kelompok Ular Tangga dan Kelompok Video}

Tabel 3

Perbedaan selisih reratapengetahuan tentang kesehatan gigi dan mulut antara pendidikan kesehatan bermedia ular tangga dan video

\begin{tabular}{lll}
\hline & $\begin{array}{c}\text { Median } \\
\text { (Minimum- } \\
\text { Maksimum) }\end{array}$ & Nilai p \\
\hline $\begin{array}{l}\text { Ular } \\
\text { Tangga } \\
(\mathrm{n}=37)\end{array}$ & $8,00(6-13)$ & $<0,001$ \\
$\begin{array}{l}\text { Video } \\
(\mathrm{n}=37)\end{array}$ & $9,00(5-12)$ & \\
\hline $\mathrm{Uji}$ & & Mann-Whitney
\end{tabular}

Tabel 3 menunjukan nilai $\mathrm{p}<0,001$, karena pvalue $<0,05$ sehingga $\mathrm{H} 1$ ditolak dan $\mathrm{Ha}$ diterima. Hasil ini menunjukkan secara 465esehatan terdapat perbedaaan yang signifikan rerata selisih pengetahuan tentang 465esehatan gigi dan mulut antara 465esehatan465 465esehatan bermedia permainan ular tangga dan 465esehatan465 465esehatan bermedia video pada siswa SDN Candi 01 Semarang. Rentang selisih lebih banyak pada responden yang mendapat 465esehatan465 465esehatan bermedia ular tangga.

\section{Pembahasan}

Penelitian ini menunjukkan bahwa kedua metode pembelajaran, permainan ular tangga dan menonton vide dapat membantu meningkatkan pengetahuan anak tentang kesehatan gigi dan mulut. Hasil ini sejalan dengan penelitian di Amerika Serikat tentang penerapan video untuk pembelajaran matematika yang menunjukkan bahwa capaian anak lebih tinggi pada kelompok yang diberi video dibandingkan dengan cara instruksi dasar (Bottge, Heinrichs, Chan, Mehta, \& Watson, 2003) dan penelitian di Bangkinang Kota, Indonesia yang menunjukkan bahwa penggunaan media audiovisual efektif untuk pembelajaran Kewarganegaraan (Ananda, 2017). Ode (2014) merujuk pernyataan Dike (1989) bahwa audiovisual mampu membuat topik yang diajarkan lebih jelas dan 
pembelajaran lebih menarik serta membuat ide-ide abstrak menjadi lebih konkrit sehingga mudah diterima oleh peserta didik (Ode \& Omokaro, 2007 dalam (Ode, 2014).

Sementara itu, hasil pengukuran pada kelompok ular tangga sejalan dengan penelitian Siyam, Nurhapsari, \& Benyamin (2015) yang menunjukkan bahwa penyuluhan menggunakan stimulasi permainan ular tangga dapat meningkatkan pengetahuan anak usia 8-11 tahun. Penelitian lain di Iran menunjukan hal serupa bahwa permainan aktif mampu meningkatkan capaian pembelajaran anak usia sekolah (Partovi \& Razavi, 2019). Hal tersebut dikarenakan pada kedua permainan tersebut memiliki keunggulan secara motorik, dimana pada permainan ular tangga siswa dituntut untuk bergerak dan aktif untuk menyelesaikan permainan. Hal ini sesuai dengan teori perkembangan psikososial Erikson yang menyatakan bahwa periode usia sekolah adalah periode dimana anak menciptakan sesuatu yang dapat diartikan bahwa anak sangat aktif pada masa ini (Hockenberry, Rodgers, \& Wilson, 2017).

Hasil Uji alternative MannWhitney menunjukkan bahwa pendidikan kesehatan menggunakan media ular tanga lebih efektif dibandingkan dengan media menonton video. Hasil ini mendukung penelitian Hamdalah (2013) yang menemukan kelompok yang diberi permainan ular tangga mengalami peningkatan pengetahuan lebih dari kelompok yang diberi kegiatan mewarnai gambar. Pembelajaran dengan kegiatan motorik atau gerak akan memberikan kesempatan bagi siswa untuk mengamati dan mengevaluasi kembali kegiatan yang telah diajarkan dan siswa tidak mudah bosan (Notoatmodjo, 2012). Hal ini dibuktikan pada penelitian di Indonesia dalam meningkatkan pengetahuan dan perilaku pola hidup bersih dan sehat pada anak usia sekolah. Pendidikan kesehatan diberikan melalui bermain sosio drama (Kusumawardani, Rekawati, \& Fitriyani, 2019)

Pada penelitian ini didapatkan rerata selisih jumlah jawaban benar kuesioner paling tinggi kelompok ular tangga adalah responden lakilaki, sedangkan pada kelompok menonton video adalah responden perempuan. Hal ini sejalan dengan penelitian Bian, Lesllie, \& Cimpian (2017) yang menunjukkan bahwa sejak usia 6 tahun anak dengan gender berbeda akan menunjukkan perbedaan ketertarikan terhadap suatu metode belajar tertentu. Anak perempuan cenderung tertarik terhadap permainan yang aktif, sedangkan anak laki-laki lebih menyukai permainan yang aktif. Karena permainan ular tangga merupakan permainan yang menuntut keaktifan pemainnya sejak permainan dimulai sampai dengan permainan selesai, maka anak lakilaki lebih menikmati permainan yang menyebabkan informasi yang diberikan selama bermain dapat diserap dengan lebih baik. Demikian pula yang terjadi pada kelompok menonton video yang merupakan jenis permainan pasif (Hockenberry et al., 2017), anak perempuan lebih 
menikmati sehingga lebih mudah menangkap informasi yang diberikan (Yusuf \& Pattisahusiwa, 2020). Presentase anak laki-laki pada kelompok ular tangga lebih besar $(75,7 \%)$ dibandingkan dengan presentase anak perempuan pada kelompok menonton video $(56,8 \%)$ sehingga ini mungkin yang menyebabkan perubahan nilai pada lebih tinggi pada kelompok ular tangga dibandingkan kelompok menonton video.

Keterbatasan penelitian ini adalah jumlah anak laki-laki pada kelompok ular tangga dan jumlah perempuan pada kelompok video tidak homogen. Penelitian selanjutnya dapat menguji kembali kedua metode ini dengan jumlah sampel yang homogen dan lebih banyak.

\section{Simpulan}

Hasil penelitian ini menunjukkan bahwa bermain ular tangga terbukti lebih efektif sebagai media pendidikan bagi anak usia sekolah dibandingkan dengan menonton video.

\section{Referensi}

Ananda, R. (2017). Penggunaan media audio visual untuk meningkatkan hasil belajar pendidikan kewarganegaraan siswa kelas IV SD Negeri 016 Bangkinang Kota. Jurnal Basicedu, 1(1), 21-30. https://doi.org/http://www.jbasic.org/in dex.php/basicedu/article/view/149

Bian, L., Lesllie, S.-J., \& Cimpian, A. (2017). Gender stereotypes about intellectual ability emerge early and influence children. Science, 335 (6323), 389-391. https://doi.org/DOI:

10.1126/science.aah6524

Bottge, B. A., Heinrichs, M., Chan, S.-Y., Mehta, Z. D., \& Watson, E. (2003). Effects of Video-Based and Applied Problems on the Procedural Math Skills of Average- and Low-Achieving Adolescents Wisconsin Center for Education Research National Tainan Teachers College, Taiwan. Journal of Special Education Technology, 18(2), 522.

https://doi.org/https://doi.org/10.1177/ 016264340301800201

Hamdalah, A. (2013). Efektivitas media cerita bergambar dan ular tangga. Jurnal Promkes, 1(2), 118-123. Retrieved from http://journal.unair.ac.id/filerPDF/jupro mkesa4369c10e3full.pdf

Harlina. (2011). Kesehatan Gigi dan Mulut. Bandung: PT Remaja Rosdakarya.

Hockenberry, M., Rodgers, C., \& Wilson, D. (2017). Wong's Essentials of Pediatric Nursing (10th ed.). Mosby.

Kantohe, Z. R., Wowor, V. N. S., \& Gunawan, P. N. (2016). Perbandingan efektivitas pendidikan kesehatan gigi menggunakan media video dan flip chart terhadap peningkatan pengetahuan kesehatan gigi dan mulut anak. Jurnal E-Gigi (eG), 44(2), 96-101.

Kusumawardani, L. H., Rekawati, E., \& Fitriyani, P. (2019). Improving diarrhoeal and clean and healthy living behaviour ( PHBS ) through collaboration socio-dramatic play ( Ko-Berdrama) in school age children. Sri Lanka Journal of Child Health, 48(3), 240245.

https://doi.org/http://dx.doi.org/10.4038 /sljch.v48i3.8759

Mckendrick, J. H. (2019). Realising the 
potential of play in Scottish education. 51(2), 137-142.

Mozelius, P., \& Öberg, L.-M. (2017). Play-based learning for programming education in primary school_The Östersund model.pdf (pp. 375-383). pp. 375-383. Retrieved from https://www.divaportal.org/smash/get/diva2:1153550/FU LLTEXT01.pdf

Notoatmodjo, S. (2012). Promosi Kesehatan Teori dan Aplikasi. Jakarta: Rineka Cipta.

Ode, E. O. (2014). Impact of audio-visual ( AVs ) resources on teaching and learning in some selected private secondary schools in makurdl. International Journal of Research in, 2(5), 195-202. Partovi, T., \& Razavi, M. R. (2019). The effect of gamebased learning on academic achievement motivation of elementary school students. Impact Journals, 68, 1-9. https://doi.org/10.1016/j.Imot.2019.101 592
Potter, P. A., Perry, A. G. (2012). Fundamental keperawatan. Jakarta: EGC.

Siyam, S. N. ., Nurhapsari, A., \& Benyamin, B. (2015). Pengaruh stimulasi permainan ular tangga tentang gingivitis terhadap pengetahuan anak usia 8-11 tahun. Odonto Dental Journal, 2(1), 25-28. Retrieved from http://jurnal.unissula.ac.id/index.php/odj /article/view/433/361

Wahyuningrum, E., Rahmat, I., \& Hartini, S. (2018). Effect of health education of sleep hygiene on sleep. Belitung Nursing Journal, 4(1), 68-75.

Yusuf, A., \& Pattisahusiwa, E. (2020). Teacher's strategies to create a conducive learning environment in the ron clark story movie. Prosodi, 14(2), 87-98. Retrieved from file://C:/Users/ASUS/Downloads/876022293-1-PB.pdf 